\title{
Methanotroph abundance not affected by applications of animal urine and a nitrification inhibitor, dicyandiamide, in six grazed grassland soils
}

\author{
Hong Jie Di • Keith C. Cameron • Ju-Pei Shen • \\ Chris S. Winefield • Maureen O'Callaghan • \\ Saman Bowatte $\cdot$ Ji-Zheng He
}

Received: 17 July 2010 /Accepted: 11 November 2010 /Published online: 1 December 2010

(C) Springer-Verlag 2010

\begin{abstract}
Purpose Methanotrophs are an important group of methane $\left(\mathrm{CH}_{4}\right)$-oxidizing bacteria in the soil, which act as a major sink for the greenhouse gas, $\mathrm{CH}_{4}$. In grazed grassland, one of the ecologically most sensitive areas is the animal urine patch soil, which is a major source of both nitrate $\left(\mathrm{NO}_{3}{ }^{-}\right)$ leaching and nitrous oxide $\left(\mathrm{N}_{2} \mathrm{O}\right)$ emissions. Nitrification inhibitors, such as dicyandiamide (DCD), have been used to mitigate $\mathrm{NO}_{3}{ }^{-}$leaching and $\mathrm{N}_{2} \mathrm{O}$ emissions in grazed pastures. However, it is not clear if the high nitrogen loading rate in the animal urine patch soil and the use of
\end{abstract}

Responsible editor: Chengrong Chen

H. J. Di $(\bowtie) \cdot$ K. C. Cameron

Centre for Soil and Environmental Research, Lincoln University, P.O. Box 84, Lincoln 7647, Christchurch, New Zealand e-mail: hong.di@lincoln.ac.nz

J.-P. Shen · J.-Z. He

State Key Laboratory of Urban and Regional Ecology, Research Centre for Eco-Environmental Sciences,

Chinese Academy of Sciences,

18 Shuangqing Road,

Beijing 100085, People's Republic of China

C. S. Winefield

Faculty of Agriculture and Life Sciences, Lincoln University, P.O. Box 84, Lincoln 7647, Christchurch, New Zealand

\section{O'Callaghan}

Lincoln Research Centre, AgResearch,

Private Bag 4749

Christchurch 8140, New Zealand

\section{S. Bowatte}

Grasslands Research Centre, AgResearch Ltd,

Tennent Drive, Private Bag 11008,

Palmerston North 4442, New Zealand nitrification inhibitors would have an impact on the abundance of methanotrophs in grazed grassland soils. The purpose of this study was to determine the effect of animal urine and DCD on methanotroph abundance in grazed grassland soils.

Materials and methods A laboratory incubation study was conducted to determine the effect of urine and DCD applications on the abundance of methanotrophs in six grazed grassland soils sampled from across New Zealand, using real-time PCR targeting the functional pmoA gene.

Results and discussion Results showed that the pmoA gene copy numbers were low in these soils, mostly below $2.36 \times$ $10^{4} \mathrm{~g}^{-1}$ soil except in the West Coast soil where pmoA gene copy number reached $8.95 \times 10^{5} \mathrm{~g}^{-1}$ soil. Most of the clones identified were aligned to the type II methanotrophs. There was no significant effect $(P<0.05)$ on the abundance of methanotrophs by the applications of urine at $1,000 \mathrm{~kg} \mathrm{~N}$ $\mathrm{ha}^{-1}$ or DCD at $10 \mathrm{~kg} \mathrm{ha}^{-1}$.

Conclusions These results suggest that the abundance of methanotrophs is not affected by urine deposition or the application of DCD to mitigate $\mathrm{NO}_{3}{ }^{-}$leaching and $\mathrm{N}_{2} \mathrm{O}$ emissions in grazed grassland soils.

Keywords Animal urine · Grassland soil · Methaneoxidizing bacteria $\cdot$ Methanotrophs $\cdot$ Nitrification inhibitor . pmoA gene $\cdot$ Real-time PCR

\section{Introduction}

Methane $\left(\mathrm{CH}_{4}\right)$ and nitrous oxide $\left(\mathrm{N}_{2} \mathrm{O}\right)$ are two greenhouse gases with a long-term global warming potential 21 and 310 times that of carbon dioxide $\left(\mathrm{CO}_{2}\right)$, respectively. In New Zealand, the agricultural sector accounts for about 
$50 \%$ of the national greenhouse gas emissions (MFE 2009), of which two thirds are $\mathrm{CH}_{4}$ mainly from enteric fermentation of grazing animals, and one third is $\mathrm{N}_{2} \mathrm{O}$ mainly from animal urine deposited on the soil.

Methanotrophs are a group of $\mathrm{CH}_{4}$-oxidizing bacteria that use $\mathrm{CH}_{4}$ as sources of carbon and energy. The oxidation of $\mathrm{CH}_{4}$ by methanotrophs in the soil provides a major sink for $\mathrm{CH}_{4}$ in the atmosphere (Hanson and Hanson 1996; Smith et al. 2000). There are two main groups of methanotrophs, depending on the pathways of carbon assimilation: type I methanotrophs in the $\gamma$-subdivision of the Proteobacteria and type II methanotrophs in the $\alpha$ subdivision of the Proteobacteria. Type I methanotrophs assimilate formaldehyde by the ribulose monophosphate pathway, whereas type II methanotrophs assimilate formaldehyde using the serine pathway (Bedard and Knowles 1989). The growth and activity of methanotrophs may be affected by a number of factors, including soil conditions, fertilizer applications, and type of vegetation cover (e.g., Hanson and Hanson 1996; Mosier et al. 1991; Zheng et al. 2008).

The first step of the $\mathrm{CH}_{4}$ oxidation process is the conversion of $\mathrm{CH}_{4}$ to methanol $\left(\mathrm{CH}_{3} \mathrm{OH}\right)$ by methane monooxygenase (MMO). There are two different forms of MMO, a soluble (sMMO) and a membrane-bound particulate form (pMMO). The sMMO is only found in a small range of taxa, whereas the pMMO is found in most methanotrophs. The structural genes of this pMMO lie in a three-gene operon, pmoCAB (Semrau et al. 1995; Stolyar et al. 1999; Gilbert et al. 2000). The pmoA gene serves as an important functional gene marker for studying methanotrophs in various environments (Smith et al. 1997; Costello and Lidstrom 1999; McDonald et al. 2008).

Another group of bacteria that is closely associated with methanotrophs in the soil is ammonia oxidizing bacteria (AOB). AOB are groups of chemoautotrophic bacteria in the $\beta$ - and $\gamma$-subgroups of Proteobacteria, which oxidize ammonia $\left(\mathrm{NH}_{3}\right)$ to nitrite $\left(\mathrm{NO}_{2}{ }^{-}\right)$(Purkhold et al. 2000; Kowalchuk and Stephen 2001). AOB may also oxidize $\mathrm{CH}_{4}$ but the specific rate of $\mathrm{CH}_{4}$ oxidation by AOB is less than $5 \%$ of that by methanotrophs (Bedard and Knowles 1989; Hanson and Hanson 1996).

In grazed grassland where animals graze outdoor pastures, one of the most ecologically significant areas in terms of carbon and nitrogen cycling is the soil under animal urine patches. As animals graze outdoor pastures, between $70 \%$ and $90 \%$ of the nitrogen $(\mathrm{N})$ ingested by the animal is returned to the soil in excreta during grazing, particularly in the urine (Jarvis 1997; Di and Cameron 2002a). The $\mathrm{N}$ loading rate under a typical dairy cow urine patch is about $1,000 \mathrm{~kg} \mathrm{Nha}^{-1}$. Most of the $\mathrm{N}$ in the animal urine is urea that, upon hydrolysis in the soil, releases ammonium $\left(\mathrm{NH}_{4}^{+}\right)$. On an annual basis, animal urine patches may cover about $25 \%$ of the grazed field under intensively grazed dairy pastures, depending on stocking rate. It is these urine patches that are responsible for most of the nitrate $\left(\mathrm{NO}_{3}{ }^{-}\right)$leaching and $\mathrm{N}_{2} \mathrm{O}$ emissions in grazed pastures (Di and Cameron 2002a; De Klein et al. 2003; Di et al. 2007).

It has been shown that following the application of animal urine to a grazed pasture soil, the population size and activity of AOB increases significantly, resulting in significantly increased nitrification rates (Di et al. 2009a), which in turn leads to increased $\mathrm{NO}_{3}{ }^{-}$leaching losses and $\mathrm{N}_{2} \mathrm{O}$ emissions (Di et al. 2009b; 2010a). However, the $\mathrm{AOB}$ growth and activity were significantly inhibited by the application of the nitrification inhibitor dicyandiamide (DCD), thus significantly reducing $\mathrm{NO}_{3}{ }^{-}$leaching and $\mathrm{N}_{2} \mathrm{O}$ emissions (Di and Cameron 2002b, 2005; Di et al. 2007). The nitrification inhibitor technology is an important tool for mitigating $\mathrm{NO}_{3}{ }^{-}$leaching and $\mathrm{N}_{2} \mathrm{O}$ emissions in grazed pastures.

However, our understanding of the microbial ecology in the animal urine patch soil is very limited. This is important because it has been shown that methane oxidation may be affected, either positively or negatively, by applications of ammonium fertilizers (e.g., Mosier et al. 1991; Willison et al. 1995; Bodelier and Laanbroek 2004). However, it is not known if methanotroph populations are affected by the deposition of animal urine in grazed pastures. In addition, because the amoA and pmoA genes are structurally similar and share similar substrates, it is also not known whether the use of the nitrification inhibitor DCD, to reduce $\mathrm{NO}_{3}{ }^{-}$ leaching and $\mathrm{N}_{2} \mathrm{O}$ emissions, would have a nontarget effect on methanotroph population dynamics in the soil affected by urine deposition.

The objectives of this study were therefore to determine the population dynamics of methanotrophs in grazed grassland as affected by animal urine inputs and by the application of a nitrification inhibitor (DCD). This was carried out by using real-time PCR to study the abundance of methanotrophs in six grazed grassland soils, with and without applications of urine and DCD. Clone library analysis was used to determine the phylogeny of the major methanotrophic taxa in the soils.

\section{Materials and methods}

\subsection{Soils}

Six soils were used for the study. Soil samples were collected in the first week of April 2008 from dairy farms in six different regions across New Zealand: Northland, Waikato, and Rotorua Lakes in the North Island and Canterbury, the West Coast, and Southland in the South 
Island. The parent materials of these soils ranged from sedimentary to volcanic. As such, their physical and chemical properties varied widely (Table 1). The pasture on these soils was a mixture of perennial ryegrass (Lolium perenne) and white clover (Trifolium repens).

For each site, soil samples were collected from 0 to $0.1 \mathrm{~m}$ depth from ten different random locations within a grazed field. The soil samples were kept cool with packed ice during transport to the laboratory and were then stored at $4^{\circ} \mathrm{C}$ until use in the incubation study described below. A subsample was taken from each soil to determine the soil water content at "field capacity" (-10 kpa) using a standard tension table technique (Ball and Hunter 1988).

\subsection{Incubation experiment}

Each of the six soils received the following three treatments: (a) control, (b) $50 \mathrm{~kg}$ urea- $\mathrm{N}+1,000 \mathrm{~kg}$ urine- $\mathrm{N}$ per ha equivalent, and (c) $50 \mathrm{~kg}$ urea-N+ $1,000 \mathrm{~kg}$ urine- $\mathrm{N}+10 \mathrm{~kg}$ DCD equivalent per ha. Each treatment was replicated four times. Treatment (b) was designed to simulate a dairy cow urine patch under grazed pasture where the $\mathrm{N}$ input from the urine was $1,000 \mathrm{~kg} \mathrm{Nha}^{-1}$, and $50 \mathrm{~kg}$ of fertilizer $\mathrm{N}$ was also applied to the grazed field, representing typical farming practice.
The nitrification inhibitor (DCD) was applied to determine its possible effect on methanotroph populations under the urine patch when it is used to treat grazed pasture soils to reduce $\mathrm{NO}_{3}{ }^{-}$leaching and $\mathrm{N}_{2} \mathrm{O}$ emissions (Di and Cameron 2002b).

For each replicate, a 1-kg soil sample (dry weight basis) was weighed into an incubation vessel and was placed in an incubator at $12^{\circ} \mathrm{C}$ for 1 week for preincubation equilibration. The $12^{\circ} \mathrm{C}$ temperature was chosen to represent the temperature in the autumn in many parts of New Zealand when nitrification inhibitors are recommended for use to reduce $\mathrm{NO}_{3}{ }^{-}$leaching and $\mathrm{N}_{2} \mathrm{O}$ emissions in grazed pastures (Di and Cameron 2005). Prior to application of treatments, soil samples were taken to determine the abundance of methanotrophs and for cloning and phylogenetic analysis.

The treatments were applied to the soils after 1 week pre-incubation. Fresh dairy cow urine was collected from lactating cows and analyzed for its total $\mathrm{N}$ concentration before being applied. DCD was applied in a dissolved liquid form. Following the application of the urea, urine, and DCD, the soil moisture content was adjusted to $80 \%$ of the water content at "field capacity" for each soil, and the soil sample within each incubation vessel was thoroughly mixed. A lid with two aeration holes (each with $0.5-\mathrm{cm}$ diameter) was placed on top of each soil

Table 1 Properties of soils used for the study

\begin{tabular}{|c|c|c|c|c|c|c|}
\hline Location & $\begin{array}{l}\text { Northland (NL) } \\
36^{\circ} 15^{\prime} 24^{\prime \prime} \mathrm{S} ; \\
174^{\circ} 31^{\prime} 20^{\prime \prime} \mathrm{E}\end{array}$ & $\begin{array}{l}\text { Waikato (WK) } \\
38^{\circ} 46^{\prime} 38^{\prime \prime} \mathrm{S} ; \\
175^{\circ} 18^{\prime} 26^{\prime \prime} \mathrm{E}\end{array}$ & $\begin{array}{l}\text { Rotorua Lakes } \\
\quad(\mathrm{RL}) 38^{\circ} 00^{\prime} 14^{\prime \prime} \\
\mathrm{S} ; 176^{\circ} 10^{\prime} 45^{\prime \prime} \mathrm{E}\end{array}$ & $\begin{array}{c}\text { Canterbury (CT) } \\
43^{\circ} 45^{\prime} 54^{\prime \prime} \mathrm{S} ; \\
171^{\circ} 41^{\prime} 25^{\prime \prime} \mathrm{E}\end{array}$ & $\begin{array}{l}\text { West Coast } \\
\text { (WC) } 42^{\circ} 42^{\prime} \\
12^{\prime \prime} \text { S; } 171^{\circ} 26^{\prime} \\
43^{\prime \prime} \text { E }\end{array}$ & $\begin{array}{l}\text { Southland } \\
\text { (SL) } 46^{\circ} 19^{\prime} \\
21^{\prime \prime} \mathrm{S} ; 168^{\circ} \\
16^{\prime} 02^{\prime \prime} \mathrm{E}\end{array}$ \\
\hline Soil type & $\begin{array}{l}\text { Waikare silty } \\
\text { clay loam }\end{array}$ & $\begin{array}{l}\text { Horotiu } \\
\text { silt loam }\end{array}$ & $\begin{array}{l}\text { Oropi silt } \\
\text { loam }\end{array}$ & $\begin{array}{l}\text { Lismore stony } \\
\text { silt loam }\end{array}$ & $\begin{array}{l}\text { Harihari recent } \\
\text { silt loam }\end{array}$ & $\begin{array}{l}\text { Mataura } \\
\text { recent sandy } \\
\text { loam }\end{array}$ \\
\hline $\begin{array}{l}\text { NZ and USDA Soil } \\
\text { Classifications } \\
\text { (Hewitt 1998; } \\
\text { Soil Survey } \\
\text { Staff 1998) } \\
\text { Particle size (\%) }\end{array}$ & $\begin{array}{l}\text { Gleyed Clay Alluvial } \\
\text { Fulvi-appodic Soil; } \\
\text { Aquic Haplohumult }\end{array}$ & $\begin{array}{l}\text { Typic Orthic } \\
\text { Allophanic } \\
\text { Soil; Typic } \\
\text { Udivitrand }\end{array}$ & $\begin{array}{l}\text { Allophanic } \\
\text { Orthic Pumice } \\
\text { Soil; Typic } \\
\text { Udivitrands }\end{array}$ & $\begin{array}{l}\text { Pallic Orthic } \\
\text { Brown Soil; } \\
\text { Udic Haplustept } \\
\text { loamy skeletal }\end{array}$ & $\begin{array}{l}\text { Mottled Fluvial } \\
\text { Recent Soil; } \\
\text { Typic } \\
\text { Fluvaquents }\end{array}$ & $\begin{array}{l}\text { Typic Fluvial } \\
\text { Recent Soil; } \\
\text { Typic } \\
\text { Udifluvents }\end{array}$ \\
\hline Sand & 11.0 & 20.4 & 47.6 & 10.5 & 4.2 & 69.1 \\
\hline Silt & 53.0 & 73.8 & 51.7 & 66.0 & 93.6 & 29.0 \\
\hline Clay & 36.0 & 5.8 & 0.7 & 23.5 & 2.2 & 1.9 \\
\hline $\mathrm{pH}\left(\mathrm{H}_{2} \mathrm{O}\right)$ & 5.7 & 5.9 & 6.1 & 5.9 & 5.4 & 5.6 \\
\hline Organic C $\left(\mathrm{g} \mathrm{kg}^{-1}\right)$ & 84.7 & 40.4 & 36.5 & 36.5 & 68.8 & 62.6 \\
\hline Total N $\left(\mathrm{g} \mathrm{kg}^{-1}\right)$ & 7.3 & 3.5 & 3.3 & 3.5 & 5.6 & 5.7 \\
\hline Olsen P (mg kg $\left.{ }^{-1}\right)$ & 53.4 & 16.9 & 48.1 & 53.0 & 46.5 & 21.1 \\
\hline $\mathrm{CEC}\left(\mathrm{cmol}_{\mathrm{c}} \mathrm{kg}^{-1}\right)$ & 32.0 & 13.0 & 17.0 & 17.5 & 15.0 & 19.0 \\
\hline Exch. $\mathrm{Ca}^{2+}\left(\mathrm{cmol}_{\mathrm{c}} \mathrm{kg}^{-1}\right)$ & 20.8 & 7.1 & 12.0 & 10.3 & 5.0 & 6.7 \\
\hline Exch. $\mathrm{Mg}^{2+}\left(\mathrm{cmol}_{\mathrm{c}} \mathrm{kg}^{-1}\right)$ & 2.74 & 0.27 & 0.79 & 0.53 & 0.94 & 0.9 \\
\hline Exch. $\mathrm{K}^{+}\left(\mathrm{cmol}_{\mathrm{c}} \mathrm{kg}^{-1}\right)$ & 0.57 & 0.19 & 0.29 & 0.71 & 0.25 & 0.24 \\
\hline Base saturation (\%) & 75.3 & 60.6 & 76.8 & 66.0 & 40.4 & 42.5 \\
\hline
\end{tabular}


container. These incubation vessels were then placed randomly inside the incubator with a constant temperature at $12^{\circ} \mathrm{C}$. The soil moisture content was maintained at $80 \%$ of field capacity by adjusting the weight of each vessel using de-ionized water. The soil samples were incubated for about 3 months during which time subsamples were taken to determine the abundance of methanotrophs using real-time PCR.

\subsection{Quantification of methanotroph abundance}

Soil samples (about $20 \mathrm{~g}$ ) were taken from the incubation containers $1,7,21,49$, and 92 days after the application of the treatments, and DNA was extracted to determine the abundance of methanotrophs by quantifying the $p m o A$ gene copy numbers using real-time PCR. A subsoil sample was also taken at the same time and used to determine the soil moisture content.

For real-time PCR analysis, soil samples $(0.4 \mathrm{~g})$ were extracted with MoBio Powersoil ${ }^{\mathrm{TM}}$ DNA isolation kits (San Diego, CA) according to the manufacturer's instructions. DNA was eluted with $100 \mu$ l of solution C6 (MoBio Laboratories, CAT. No $12888-100$ ) and stored at $-80^{\circ} \mathrm{C}$ before being analyzed.

All the PCR reactions were set up using the CAS- 1200 Robotic liquid handling system (Corbett Life Science, Australia), and real-time PCR was performed on a Rotorgene 6000 (Corbett Life Science, Australia). Possible inhibition of the real-time PCR was assessed by running a series of tenfold dilutions of the extracted DNA and determining the amplification efficiency of each diluted sample. Inhibition was observed without dilution, but high amplification efficiencies of $92-99 \%$ were obtained after a tenfold dilution. The DNA sample was thus diluted ten times to minimize inhibition. The pmo $A$ gene was quantified using the primer pair A189gc (5'GGNGACTGGGACTTCTGG-3') and Mb661 (5'CCGGMGCAACGTCYTTACC-3'; Costello and Lidstrom 1999) with SYBR ${ }^{\circledR}$ Premix Ex Taq ${ }^{\mathrm{TM}}$ (TaKaRa, Japan). The $20 \mu \mathrm{l}$ reaction mixtures consisted of $10.0 \mu \mathrm{l}$ of $\mathrm{SYBR}^{\circledR}$ Premix Ex Taq ${ }^{\mathrm{TM}}$ plus primers and $1.5 \mu \mathrm{l}$ of template DNA. Real-time PCR assay was carried out using the following thermal profile: $2 \mathrm{~min}$ at $94^{\circ} \mathrm{C}$, followed by 40 cycles of $20 \mathrm{~s}$ at $94^{\circ} \mathrm{C}, 45 \mathrm{~s}$ at $60^{\circ} \mathrm{C}$, and $30 \mathrm{~s}$ at $72^{\circ} \mathrm{C}$. A melting curve analysis was performed to confirm PCR product specificity after amplification by measuring fluorescence continuously as the temperature increased from $50^{\circ} \mathrm{C}$ to $99^{\circ} \mathrm{C}$.

Standard curves for real-time PCR were developed as below. Briefly a $p m o A$ gene fragment (verified by DNA sequencing) was purified (PCR clean up kit; Axygen, USA) and cloned into the pGEM-T Easy Vector (Promega, Madison, WI, USA). The resulting ligation mix was transformed in Escherichia coli JM109 competent cells (Promega, Madison, WI, USA) and plasmids used as standards for quantitative analyses. The concentration of plasmid DNA was determined on a Qubit ${ }^{\mathrm{TM}}$ fluorometer (Invitrogen, Auckland, New Zealand), and the copy numbers of target genes were calculated directly from the concentration of the extracted plasmid DNA. Tenfold serial dilutions of a known copy number of the plasmid DNA were subjected to real-time PCR assay in triplicate to generate an external standard curve. High efficiencies of 96-100\% were obtained in $p m o A$ gene amplification, with the $R$ value ranging between 0.998 and 0.999 .

\subsection{Cloning, sequencing, and phylogenetic analysis}

The PCR products from the control soils collected before the start of the incubation experiment were used for cloning, sequencing, and phylogenetic analysis. One microliter of DNA sample was used for PCR amplification. A nested PCR approach was carried out (McDonald et al. 2008). The primer pair A189f/A682r was used in the first PCR. This PCR product was then used as the template DNA for the second PCR using the primer pair A189f/ mb661. PCR products were ligated to the TOPO ${ }^{\circledR}$ vector (Invitrogen, Auckland, New Zealand) and transformed into E. coli cells (Invitrogen). From each sample, 20 colonies were randomly selected and screened using colony PCR with A189/mb661. Ten positive PCR clones were selected for sequencing to determine the major species. These colonies were grown overnight in LB and plasmids extracted using the QIAprep spin miniprep kit (Qiagen, Crawley, UK). DNA sequencing was from the M13 primer site and used Big Dye terminator v3.1 reaction mix (Allan Wilson Centre, Palmerston North, New Zealand).

Methanotroph DNA sequences were compared against those on the GenBank with the BLAST program (www. ncbi.nlm.nih.gov/BLAST). Partial protein sequences (157 amino acid positions) were identified using the "DNA to protein translation" computer program. The sequences were aligned with BLAST search program and similarity analysis were performed with DNAStar and DNAMAN version 4.0. Phylogenetic analyses were conducted using MEGA version 3.0 (Kumar et al. 2004), and the neighborjoining tree was constructed using Kimura 2-parameter distance with 1,000 replicates to produce Bootstrap values.

\section{Results}

3.1 Methanotroph populations in six grassland soils

The population abundance of methanotrophs, as shown by the pmoA gene copy numbers, varied considerably in the 


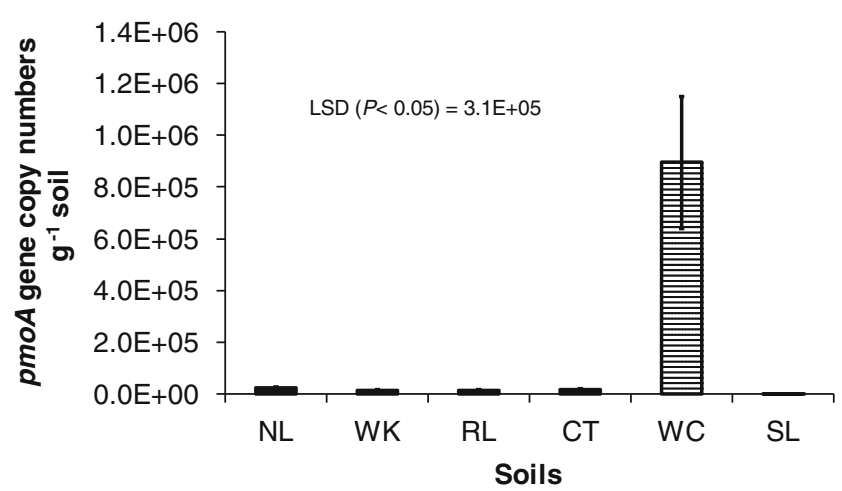

Fig. 1 Copy numbers of pmoA gene (copies $\mathrm{g}^{-1}$ soil) in the control soils before the start of the incubation study. $N L$ Northland soil, $W K$ Waikato soil, $R L$ Rotorua Lakes soil, $C T$ Canterbury soil, $W C$ West Coast soil, SL Southland soil. Error bars in the graph are the standard error of the mean (SEM)

control soils at the start of the incubation experiment (Fig. 1). The methanotroph abundance was low in five of the six soils studied (Northland, Waikato, Rorotua Lakes, Canterbury, and Southland), with the pmoA gene copy numbers below $2.36 \times 10^{4} \mathrm{~g}^{-1}$ soil. The $p m o A$ gene copy numbers were much higher in the West Coast soils, reaching $8.95 \times 10^{5} \mathrm{~g}^{-1}$ soil.

Thirty-one different methanotroph clones with different partial pmoA protein sequences were identified by phylogenetic analysis. Most of the methanotroph clones were closely aligned to type II methanotrophs. Only three clones were closely aligned with type I methanotrophs (Fig. 2). The methanotroph clones from the Canterbury soil were all clustered together in the phylogenetic tree, as were the clones in the Waikato soil (see Fig. 2). Most of the clones were closely related to the Methylocystis sp. However, none of the Canterbury clones were closely related to any known methanotrophic strains.

\subsection{Effect of urine and DCD on methanotroph abundance}

The application of animal urine did not have a significant effect $(P>0.05)$ on the methanotroph abundance in any of the six grassland soils (Fig. 3). Similarly, the application of the nitrification inhibitor DCD also did not significantly affect the methanotroph population abundance $(P>0.05)$. Although the $p m o A$ gene copy numbers varied slightly with time in some of the soils, overall, there was no significant effect $(P>0.05)$ of either urine or DCD on the pmoA gene copy numbers during the course of the incubation.

\section{Discussion}

Results from this study clearly show that the application of animal urine at a typical rate equivalent to $1,000 \mathrm{~kg} \mathrm{Nha}^{-1}$ in six grazed grassland soils had little or no impact on the abundance of methanotrophs. This is in clear contrast to the abundance or activity of the ammonia oxidizing bacteria,
Fig. 2 Phylogenetic relationships among $p m o A$ gene sequences retrieved from the control soils before the start of the incubation study.

Designation of the clones in bold includes the site and the clone and clone information with the similarity larger than $98 \%$ in brackets. Bootstrap values $(>50 \%)$ are indicated at branch points. The scale bar represents $5 \%$ estimated sequence divergence. $N L$ Northland soil, $W K$ Waikato soil, $R L$ Rotorua Lakes soil, $C T$ Canterbury soil, $W C$ West Coast soil, $S L$ Southland soil, $M O B$ methane-oxidizing bacteria

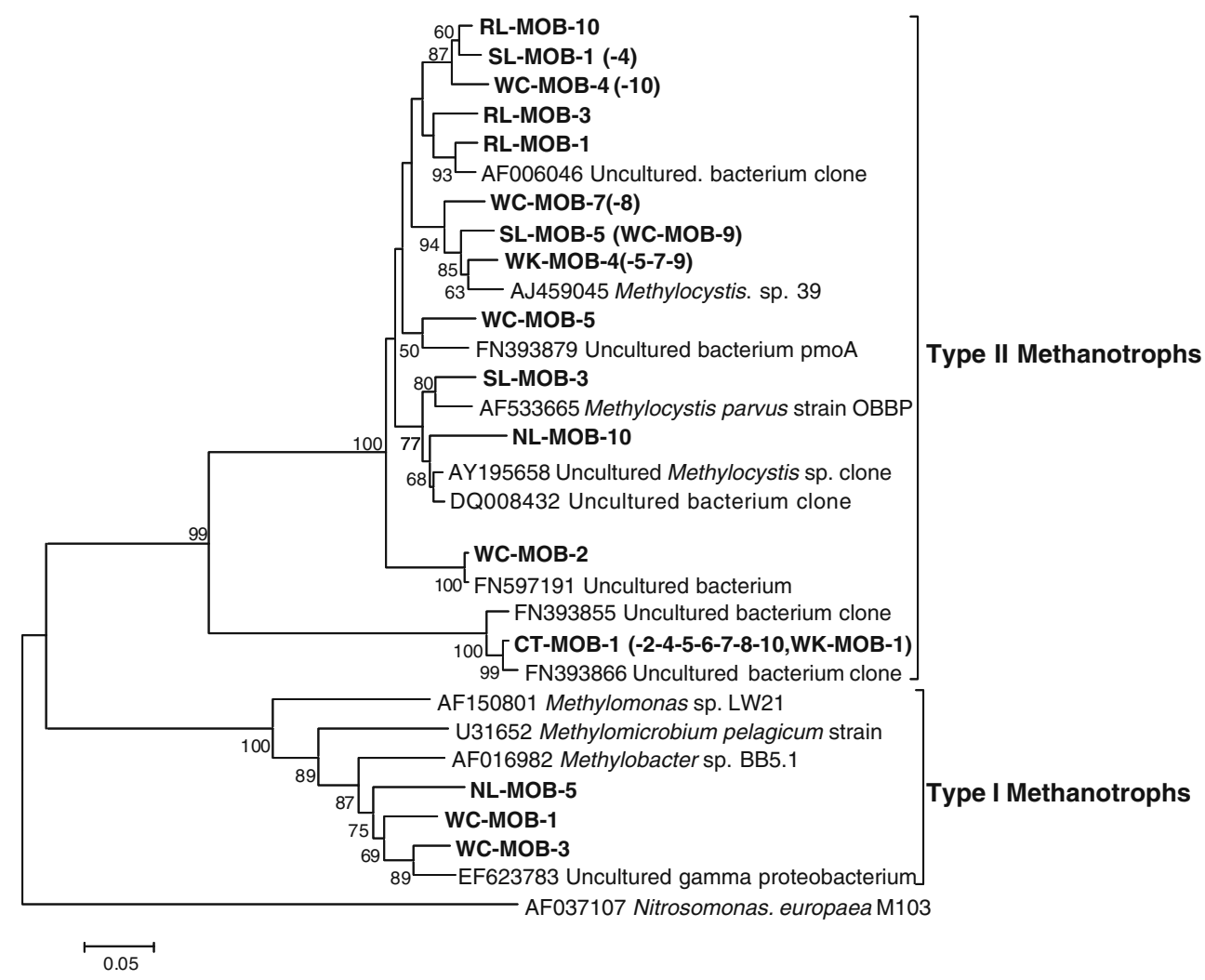


a

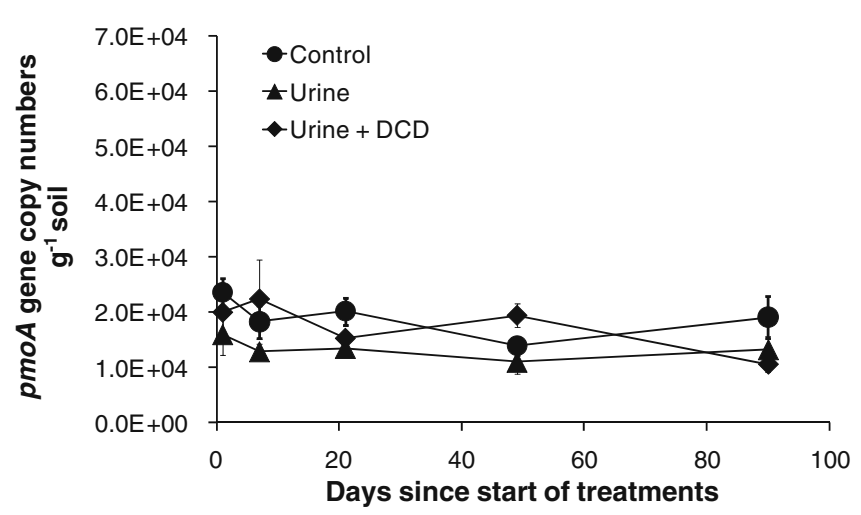

C

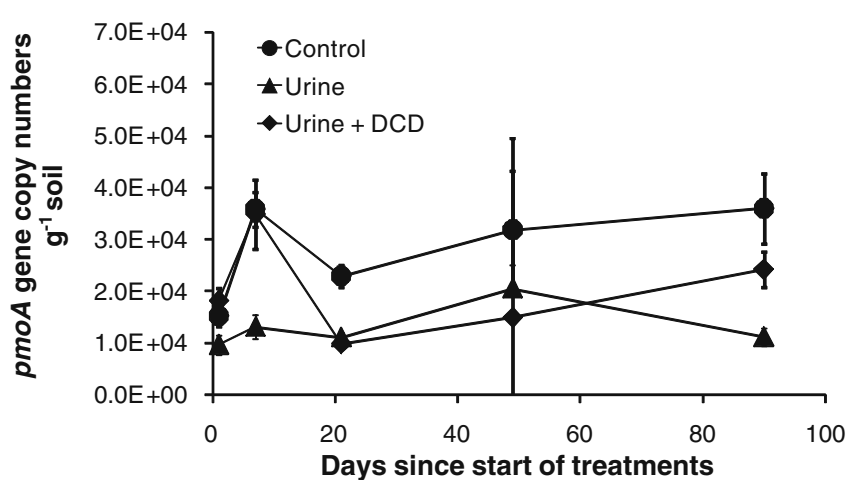

e

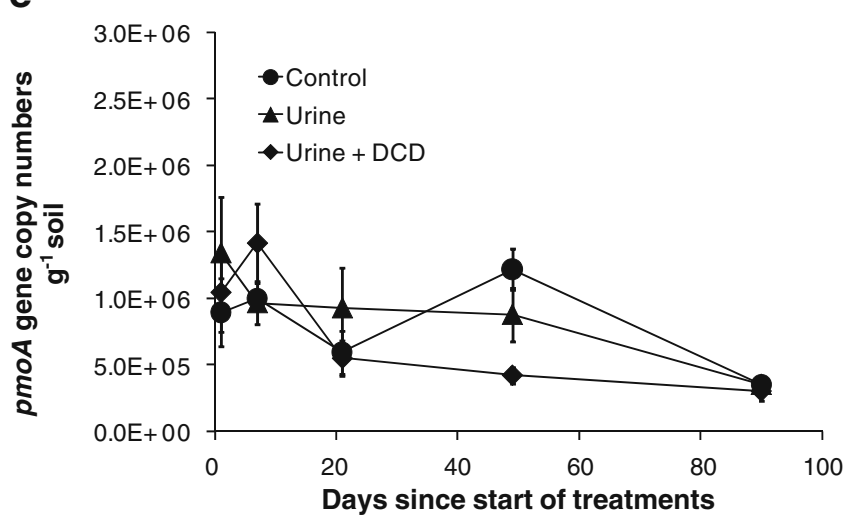

b

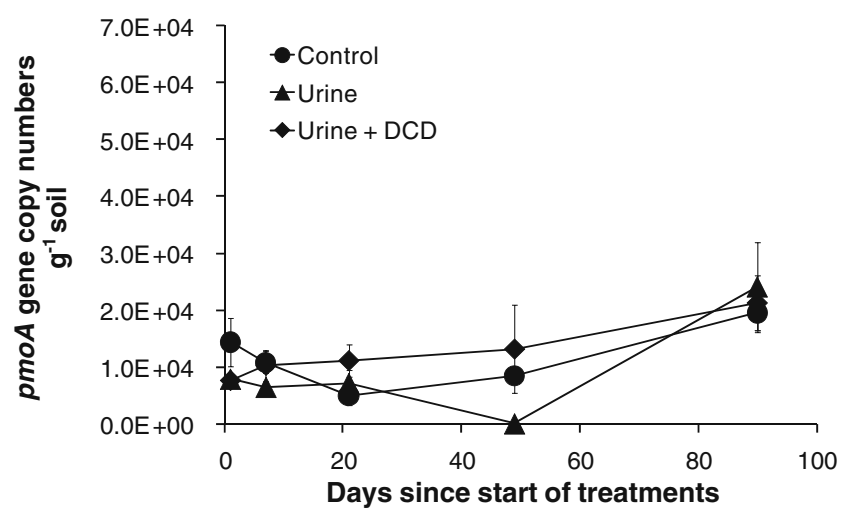

d

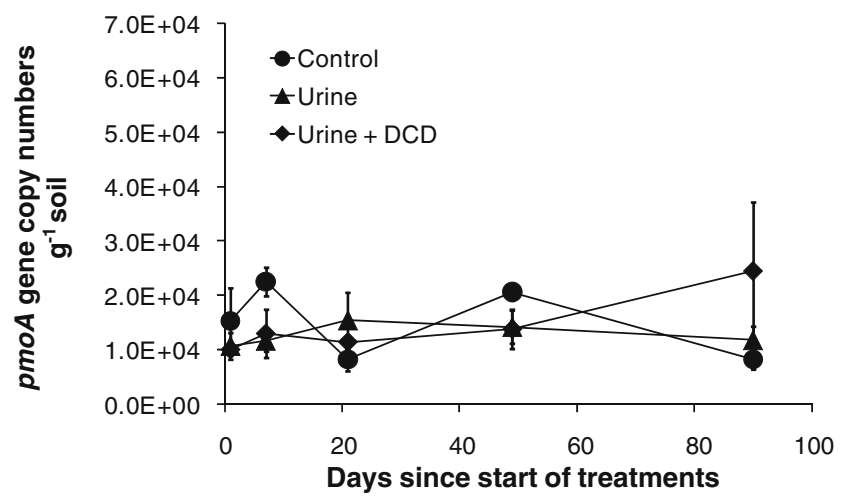

f

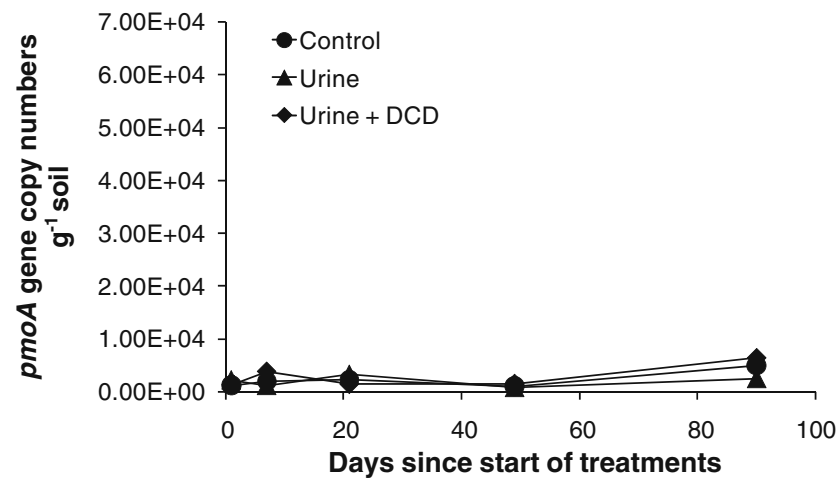

Fig. 3 pmoA gene copy numbers as affected by the application of animal urine and DCD. a Northland soil. b Waikato soil. c Rotorua Lakes soil. d Canterbury soil. e West Coast soil. f Southland soil. Error bars in the graph show the standard error of the mean (SEM)

which increased significantly in response to the animal urine application (Di et al. 2009a, 2010b). About 90\% of the $\mathrm{N}$ in the animal urine is urea, which is quickly transformed into $\mathrm{NH}_{4}^{+}$in the soil (Di and Cameron 2002a). Studies on methanotroph abundance in grazed grassland soils are limited, but studies in other agroecosystems have shown both positive and negative impacts on methane oxidation or methanotrophs by the application of ammonium $\left(\mathrm{NH}_{4}^{+}\right)$fertilizers (e.g., Steudler et al. 1989; Mosier et al. 1991; Bodelier et al. 2000; Zheng et al. 2008). For example, Bodelier et al. (2000) reported increased methanotroph biomass as a result of ammonium fertilizer application in paddy soils. While Zheng et al. (2008) found that methanotroph populations were inhibited when ammonium fertilizer was applied alone, but were stimulated when ammonium and potassium fertilizers were applied together. These results suggest that the impact of ammonium fertilizer application on methanotrophs and on methane oxidation may vary depending on soil conditions. The soil conditions in grazed grassland are clearly different from those of paddy soils and further research in grazed grassland ecosystems is necessary. 
The nitrification inhibitor DCD has been shown to be highly effective in inhibiting the growth and activity of AOB in the urine patch soils of grazed grassland (Di et al. 2009a, 2010b) and has now been developed into a mitigation technology to reduce $\mathrm{NO}_{3}{ }^{-}$leaching and $\mathrm{N}_{2} \mathrm{O}$ emissions from urine patch soils in grazed grassland (e.g., Di and Cameron 2002b; Di and Cameron 2005; Di et al. 2007). However, until now it was not known if DCD would also inhibit the growth of methanotrophs in the soil, leading to reduced methane oxidation rates. Results from this study clearly show that the application of DCD to the urine patch soils had no significant effect on the abundance of methanotrophs in all six soils.

The pmoA gene copy numbers found in this study were two to three orders of magnitude lower than those reported for paddy soils (Zheng et al. 2008). This is probably related to the different soil conditions of the two agroecosystems. The minor temporal variations of the pmoA gene copy numbers in these soils (see Fig. 3d, e) were probably in response to the minor variations in soil conditions during the incubation. Attempts were also made in this study to determine the transcriptional activity of the pmoA gene using reverse-transcription PCR (RTPCR), but the RNA levels were below the detection limit (data not presented). This again shows not only the low population abundance but also low activity of methanotrophs in these grassland soils. The low pmoA gene copy numbers also support the low methane oxidation rates observed for grazed grassland soils compared with other ecosystems, e.g., native beech or shrubland (Tate et al. 2007; Saggar et al. 2008).

It is interesting that the majority of the clones were aligned to type II methanotrophs, predominantly Methylocystis sp. Type II methanotroph species were also found to be dominant in paddy soils (Zheng et al. 2008). However, Singh et al. (2009) reported that type II methanotrophs were dominant in all the soils studied but were more so in the pine soil than in pasture soil. Environmental conditions, such as moisture and temperature, may also affect the growth of methanotrophs. For example, Horz et al. (2005) found that relative abundance of methanotrophs declined with increased precipitation and temperature. Clearly, further research is required to understand the soil, environmental, and management conditions that may affect the community composition and abundance of methanotrophs in different ecosystems. In addition, further research is being conducted to identify the clones from this study that were not aligned to known sequences. Nevertheless, the results from this study clearly show that the application of the nitrification inhibitor (DCD) does not have an adverse effect on the population abundance of methanotrophs under the soil conditions of this study.
Acknowledgments We would like to thank the New Zealand Foundation for Research, Science and Technology (FRST) for the funding; Drs. Ross Monaghan, Stewart Ledgard, and Mark Sheppard of AgResearch and Drs. Bruce Thorrold and Deanne Waugh of Dairy NZ for their assistance with soil sampling and Emily Gerard and Shona Brock of AgResearch and Jie Lei, Steve Moore, Carole Barlow, Trevor Hendry, and Neil Smith of Lincoln University for their technical support.

\section{References}

Ball BC, Hunter R (1988) The determination of water release characteristics of soil cores at low suctions. Geoderma 43:195-212

Bedard C, Knowles R (1989) Physiology, biochemistry and specific inhibitors of $\mathrm{CH}_{4}, \mathrm{NH}_{4}$ and $\mathrm{CO}$ oxidation by methanotrophs and nitrifiers. Microbiol Rev 53:68-84

Bodelier PLE, Laanbroek HJ (2004) Nitrogen as a regulatory factor of methane oxidation in soils and sediments. FEMS Microbiol Ecol 47:265-277

Bodelier PLE, Roslev P, Henckel T, Frenzel P (2000) Stimulation by ammonium-based fertilizers of methane oxidation in soil around rice roots. Nature 403:421-424

Costello AM, Lidstrom ME (1999) Molecular characterization of functional and phylogenetic genes from natural populations of methanotrophs in lake sediments. Appl Environ Microbiol 65:5066-5074

De Klein CAM, Barton L, Sherlock RR, Li Z, Littlejohn RP (2003) Estimating a nitrous oxide emission factor for animal urine from some New Zealand pastoral soils. Aust J Soil 41:381-399

Di HJ, Cameron KC (2002a) Nitrate leaching in temperate agroecosystems: sources, factors and mitigating strategies. Nutr Cycl Agroecosyst 64:237-256

Di HJ, Cameron KC (2002b) The use of a nitrification inhibitor, dicyandiamide (DCD), to reduce nitrate leaching and nitrous oxide emissions in a simulated grazed and irrigated grassland. Soil Use Manage 18:395-403

Di HJ, Cameron KC (2005) Reducing environmental impacts of agriculture by using a fine particle suspension nitrification inhibitor to decrease nitrate leaching from grazed pastures. Agric Ecosyst Environ 109:202-212

Di HJ, Cameron KC, Sherlock RR (2007) Comparison of the effectiveness of a nitrification inhibitor, dicyandiamide (DCD), in reducing nitrous oxide emissions in four different soils under different climatic and management conditions. Soil Use Manage 23:1-9

Di HJ, Cameron KC, Shen JP, Winefield CS, O'Callaghan M, Bowatte S, He JZ (2009a) Nitrification driven by bacteria and not archaea in nitrogen rich grassland soils. Nat Geosci 2:621-624

Di HJ, Cameron KC, Shen JP, He JZ, Winefield CS (2009b) Nitrate leaching from grazed grassland as affected by a nitrification inhibitor, dicyandiamide, and relationships with ammonia oxidizing bacteria and archaea. Soil Use Manage 25:454-461

Di HJ, Cameron KC, Sherlock RR, Shen JP, He JZ, Winefield CS (2010a) Nitrous oxide emissions from grazed grassland as affected by a nitrification inhibitor, dicyandiamide, and relationships with ammonia oxidizing bacteria and archaea. J Soils Sediments 10:943-954

Di HJ, Cameron KC, Shen JP, Winefield CS, O'Callaghan M, Bowatte S, He JZ (2010b) Ammonia oxidizing bacteria and archaea grow under contrasting soil nitrogen conditions. FEMS Microbiol Ecol 72:386-394

Gilbert B, McDonald IR, Finch R, Stafford GP, Nielsen AK, Murrell JC (2000) Molecular analysis of the pmo (particulate methane 
monooxygenase) operons from two type II methanotrophs. Appl Environ Microbiol 66:966-975

Hanson HS, Hanson TE (1996) Methanotrophic bacteria. Microbiol Rev 60:439-471

Hewitt AE (1998) New Zealand soil classification, 2nd edn. Manaaki Whenua, Lincoln, Canterbury, New Zealand

Horz HP, Rich V, Avrahami S, Bohannan BJM (2005) Methaneoxidizing bacteria in a California upland grassland soil: diversity and response to simulated global change. Appl Environ Microbiol 71:2642-2652

Jarvis SC (1997) Emission processes and their interactions in grassland soils. In: Jarvis SC, Pain BF (eds) Gaseous nitrogen emissions from grasslands. CAB International, Wellingford, pp 1-17

Kowalchuk GA, Stephen JR (2001) Ammonia-oxidizing bacteria: a model for molecular microbial ecology. Annu Rev Microbiol 55:485-529

Kumar S, Tamura K, Nei M (2004) MEGA3: integrated software for molecular evolutionary genetics analysis and sequence alignment. Brief Bioinform 5:150-163

McDonald IR, Bodrossy L, Chen Y, Murrell JC (2008) Molecular ecology techniques for the study of aerobic methanotrophs. Appl Environ Microbiol 74:1305-1315

MFE (2009) New Zealand's greenhouse gas inventory 1990-2007. Ministry for the Environment, Wellington

Mosier AR, Schimel DS, Valentine DW, Bronson K, Parton WJ (1991) Methane and nitrous oxide fluxes in native fertilized and cultivated grasslands. Nature 350:330-332

Purkhold U, Pommerening-Röser A, Juretschko S, Schmid MC, Koops HJ, Wagner M (2000) Phylogeny of all recognized species of ammonia oxidizers based on comparative 16S rRNA and $a m o A$ sequence analysis: implications for molecular diversity surveys. Appl Environ Microbiol 66:5368-5382

Saggar S, Tate R, Giltrap DL, Singh J (2008) Soil-atmosphere exchange of nitrous oxide and methane in New Zealand terrestrial ecosystems and their mitigation options: a review. Plant Soil 309:25-42

Semrau JD, Chistoserdov A, Lebron J, Costello AM, Davagnino J, Kenna EM, Holmes AJ, Finch R, Murrell JC, Lidstrom ME
(1995) Particulate methane monooxygenase genes in methanotrophs. J Bacteriol 177:3071-3079

Singh BK, Tate KR, Ross DJ, Singh J, Dando J, Thomas N, Millard P, Murrell C (2009) Soil methane oxidation and methanotroph responses to afforestation of pastures with Pinus radiata stands. Soil Biol Biochem 41:2196-2205

Smith KS, Costello AM, Lidstrom ME (1997) Methane and trichloroethylene oxidation by an estuarine methanotroph, Methylobacter sp. strain BB5.1. Appl Environ Microbiol 63:46174620

Smith KA, Dobbie KE, Ball BC, Bakken LR, Sitaula BK, Hansen S, Brumme R, Borken W, Christensen S, Priemé A, Fowler D, Macdonald JA, Skiba U, Klemedtsson L, Kasimir-Klemedtsson A, Degórska A, Orlanski P (2000) Oxidation of atmospheric methane in Northern European soils, comparison with other ecosystems, and uncertainties in the global terrestrial sink. Glob Chang Biol 6:791-803

Soil Survey Staff (1998) Keys to soil taxonomy, 8th edn. United States Department of Agriculture, Washington, DC

Steudler PA, Bowden RD, Mellilo JM, Aber JD (1989) Influence of nitrogen fertilization on methane uptake in temperate forest soil. Nature 341:314-316

Stolyar S, Costello AM, Peeples TL, Lidstrom ME (1999) Role of multiple gene copies in particulate methane monooxygenase activity in the methane-oxidizing bacterium Methylococcus capsulatus Bath. Microbiology 145:1235-1244

Tate KR, Ross DJ, Saggar S, Hedley CB, Dando J, Singh BK (2007) Methane uptake in soils from Pinus radiata plantations, a reverting shrubland and adjacent pastures: effects of landuse change, and soil texture, water and mineral nitrogen. Soil Biol Biochem 39:1437-1448

Willison TW, Webster CP, Goulding KWT, Powlson DS (1995) Methane oxidation in temperate soils: effects of land use and the chemical form of nitrogen fertilizer. Chemosphere 30:539-546

Zheng Y, Zhang LM, Zheng YM, Di HJ, He JZ (2008) Abundance and community composition of methanotrophs in a Chinese paddy soil under long-term fertilization practices. J Soils Sediments 8:406-414 